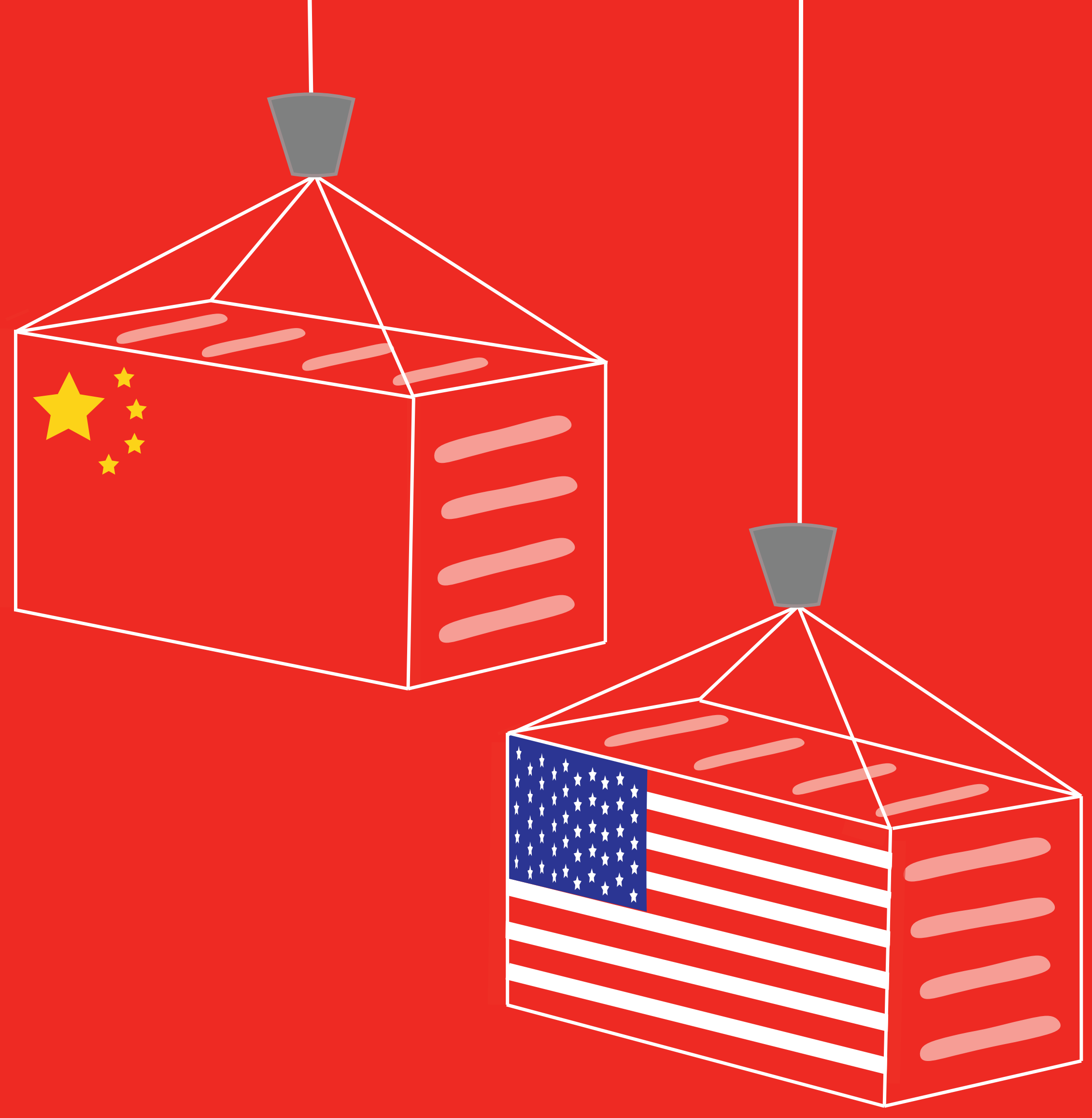

\title{
The Impact of Trumpian Trade on Canadian Agriculture: Evidence from Commodity Analyses
}

Victoria Flaherty

Edited by Felipe Aas and Juliette Mennicken

ABSTRACT - It is generally understood that Canada's close trading relationship with the United States helps power its export-dependent economy. This understanding was challenged in the wake of the US-China trade war that began in 2018. The trade war, which created opportunities for countries to fill the void left by American products in the Chinese market, was a chance for Canada to sink its teeth into China's need for agricultural commodities. By examining Canada's trading relationship with China during the trade war at a commodity level across five different products, this paper ascertains the factors that determined why Canadian lobster fishers jumped for joy while canola farmers floundered. This examination exposes how Canada-China tensions arose because Canada's extradition with the US severely depressed its ability to sell certain agricultural goods to China. 
$\mathrm{T}$ he Canadian economy is characterized by its reliance on export commodities, and, as a result, by its reliance on solid trading relationships with countries that have large consumer bases - countries like the United States (US) and China. In fact, these countries are Canada's top two trading partners, accounting for 79.3 per cent of its exports (World Bank 2019). Thus, when China and the US, the two largest economies in the world, initiated a quaking trade war in 2018, disruption ensued (Kalsie and Arora 2019,1). In the trade war's wake, not only did the US and China get hurt economically, but further, other countries' economies fell victim to the fault lines created (Library of Congress 2019; UNCTAD 2019). However, a significant space opened in the Chinese market as the sale of US products to Chinese consumers became deeply depressed (Swanson and Rappeport 2020). The attractiveness of this newly available space in the Chinese market to third party nations cannot be overstated in light of China's massive population and buying power. Thus, this paper will exar will examine how the trade war cracked open opportunities for Canada's exportbased economy to rev up its exportation to China by taking the reins from the US, following tariffs that made US agricultural goods unattractive for Chinese consumers. The scale of this void is Farm Bureau, who stated that "[American] farmers have lost the vast majority of what was once a $\$ 24$ billion market in China" (Hass and Denmark 2020).

It is clear that opportunities for export growth are distributed asymmetrically within a given country and, further, within a given sector. The scope of this assessment is confined to the agriculture sector due to the size of the void that opened in the market amidst China's decisions to raise tariffs on US agricultural imports. Therefore, one must examine the impacts of the US-China trade war on Canadian agricultural trade with China by examining specific commodities. Through this examination, it becomes clear that the success of Canadian agricultural products' penetration into the Chinese market has been impacted primarily by comparative advantages, commodity pricing, and a diplomatic spat between Canada and China that resulted due to a US-Canada treaty. By parameterizing my analysis to the commodity-level within the agricultural sector, it becomes apparent that agriculture, one of Canada's key industries, has been diversely impacted by this trade war. The agricultural sector was chosen for examination due to the unique character of the tariffs placed on the US by China and the strength of the Canadian agricultural sector. Thus, the trade war that came about as a result of Trumpian trade policies may have theoretically provided ample opportunity for Canadian exports to penetrate the Chinese market (Hubert et al 2019). However, Canadian agricultural products have had varied degrees of success in their attempts to penetrate the Chinese China-Canada tensions. In the case of commodities that were not affected by these tensions, namely lobster and wheat, Canadian goods were successful in penetrating the Chinese market. This paper will explore why other commodities, such as pork, canola and soybeans, floundered and failed to fill the void left by American goods in the Chinese market

\section{Tweets, Tariffs, Tech: The Historic and \\ Situational Context of US-China}

\section{Relations}

The US and China have a complex history of political engagements and trading activity, which began in a diplomatic sense when the US formally recognized China in 1979 (Kalsie and Arora 2019, $3-4)$. Since then, China has proven to be a hungry competitor and an attention-commanding producer, with its gross domestic product (GDP) growing, on average, by 9.6 per cent per annum (Zhang 2018 , 54). In addition to its economic gravity, China continues to grow substantially in terms of political, cultural, and technological power. Many scholars evaluating systems-level pressures on the international system point to the fact that China's rising prominence presents a security threat to the US' power. This is exhibited by the "China Threat" theory, which highlights China's ballooning power and the inconceivability that China can have a peaceful rise on its way to being a rivalling superpower of the US (Al-Rodhan 2007, 41-44).
Although the security elements of the trade war are not as relevant to Canadian agricultural exports as the purely economic conditions, I would be remiss to omit that the US-China trade war is embroiled in a deep history of political power struggles and does not exist in a purely economic vacuum (Kalsie and Arora 2019, 1). In fact, it is important to indicate that many scholars have pointed to the reasoning for US President Donald Trump's actions during the trade war as being twofold: firstly, his motivations were economic, due to his perception that the USChina trading relationship has been more beneficial for China. Secondly, the Trump administration wanted to slow China's rise as a high-powered, high-tech global superpower (Zhang 2018, 56). While vying for the oval office, Trump was adamant in his platform about his intent to rework American trade policy. He called China's entry into the World Trade Organization (WTO) "one of the greatest thefts in world history" and used powerful rhetoric to mobilize this as an election issue (Rushe 2019). Once inaugurated, the Trump administration began the process of renegotiating trade conditions through tariff adjustments and agreement frameworks across an array of sectors. Trump ascertained that China was manipulating its currency, obstructing market access, and stealing intellectual property. Trump pointed to a figure that stated that the US was running a US\$500 billion trade deficit with China, which overestimated the trade deficit by US $\$ 165$ billion but nonetheless provided him with fodder to seek to correct this deficit. This attempt began in March 2017, when Trump signed two executive orders concerning relations with China (Kalsie and Arora 2019, 7). The first called for tighter tariff enforcement in anti-subsidy and anti-dumping trade cases, while the second ordered a review of the roots of US trade deficits (The White House 2017). In January 2018, Trump ordered the US to commence an investigation using Section 301 of the Trade Act of 1974 to examine claims of Chinese theft of American intellectul proper Congruently, Trump's rhetoric became more adversarial towards China, notably when Trump told media sources that he would be willing to impose a "big fine" on China. Beginning in spring 2018, the US and China began a seesaw of imposing tariffs and banning products that saw the two countries placing billions of dollars in tariffs, duties, and bans on the other country. In December 2018, the two countries agreed to a 90-day halt on new tariffs, including Trump's agreement to delay the scheduled tariff increase until early March, at which point talks were to take place. Further, China agreed to buy a substantial amount of US products. The following February, Trump extended the March deadline on tariff increases, which left future increases on an open-ended basis and continued to adhere to his plan to bump tariffs up to 25 per cent throughout the summer of 2019. In June, Trump and Chinese President Xi Jinping agreed to rekindle trade talks ahead of a meeting scheduled at the Group of 20 summit. At the G20, the two sides agreed to restart trade talks after concessions from both, as Trump agreed to imposing no new tariffs and to an easing of restrictions on Huawei, a Chinese telecommunications company, and China agreed to purchase new

However, in August 2019, US and China representatives underwent two days of trade talks with little progress. This led to complaints voiced by Trump that China had failed to keep their promise to buy more US farm products. Trump er cent tariff on US\$300 billion cent already levied on US $\$ 250$ billion worth of Chinese goods. The Chinese Ministry of Commerce responded to this by halting the purchase of US agricultural products. After the US markets closed, the Treasury said that it had determined that China was manipulating its currency, as the yuan weakened past the key 7 per US dollar level which sent equity markets sharply lower. In September 2019, the US and China had deputies meet, resulting in the cancellation of a planned Chinese visit to US farming regions. Despite attempts to reconcile, American tariffs continued to be applied to approximately US\$125 billion worth of Chinese goods, which included popular items such as bluetooth headphones and footwear, and China announced that it would impose additional retaliatory tariffs against US\$75 billion worth of 
US goods, which put up to 10 per cent extra on top of existing rates. In October 2019, the US banned firms from selling to twenty-eight Chinese companies over alleged human rights violations, which China denounced as an interference in sovereignty (Swanson and Mozur 2019). According to Chinese officials, this soiled the atmosphere surrounding the trade talks. Eventually, in early 2020, the US and China came to an agreement that stipulated loosening levies and buying hundreds of millions of dollars in products from one another. However, the terms of this agreement have not come to fruition, as international relations between the two countries have been significantly impacted by COVID-19 and the 2020 presidential election.

\section{"Everybody Loses": the Opening Void \\ in the Chinese Market}

The impact within the US and China has clearly been substantial, with struggling sectors and the need for government aid echoing in both countries (Woo 2018). This has added to the precarious trading situation, as an unclear future in trade has dampened confidence a in trade has deterred heavy investment. However, in assessing the consequences of the trade war, looking beyond these two countries at the bigger picture of the entire global market tells a more complete story. At present, there are four major strands of literature that are attempting to assess the ongoing "eyecatching" trade war (Zhang 2018, 54). Most fields of research surrounding this topic are not entirely applicable to this paper's specific focus, as much of the literature circulating focuses on the trade imbalance, jobs, and efficacy of Trump's threats. However, a relevant strand exists that analyzes the negative impacts of such wars on the international trading system, as the trade war slowed global growth in 2019 to 3.0 per cent (Heeb 2019). This strand, which widely points to the fact that the war violates the WTO's principles by spurring protectionism, posing risks for the global trading order, helps to frame this topic in international law.

While the trade conflict is underway, ebbing moments of opportunity and distress emerge for countries hoping to break into the massive
Chinese market (Aljazeera 2019). The economic impact of the war is not being shared equally, as US remains the least exposed of the world's 20 largest economies to a drop in exports, in part because of its massive consumer base. Other countries have not been as lucky, as exhibited by the IMF director's assementment of the trade war as a situation in which "everybody loses" (Shalal and Timmons 2019). In Canada, agriculture was in bad sorts in 2018, with net farm incomes (the difference between farm revenues and operating expenses) falling by nearly 21 per cent —one of the largest annual decreases in Canada ever recorded (Edmiston 2019). The trade war, however, offered a glimmer of opportunity for Canadian farmers, as an exodus of American pro from the Chinese market. Thus, a void opened in the huge Chinese market, and many countries hoped to fill that void with their countries' products. Canadian products that were positioned to fill that gap were concentrated in the agricultural sector due to specific Canadian comparative advantages.

\section{Friendship, Competition, and}

Extradition: Canada's Place in the

\section{Trade War}

The United States and Canada maintain a close relationship which has resulted in the two countries being intertwined economically, militarily, and diplomatically —as shown by the US\$1.4 trillion economic relationship between the two nations. They are each other's largest trading partner and the US serves as Canada's primary source of foreign direct investment (The Embassy of the United States in Canada n.d.). This relationship is usually lucrative and beneficial for the export-dependent northern nation. However, the belief that the US-Canada bilateral relationship is always beneficial to Canada is facing a challenge in light of the events and fallout of December 2018. This is when Canadian authorities arrested Meng Wanzhou, the Chief Financial Officer of the Chinese tech giant Huawei, pursuant to a US extradition request that fell under a Canada-US extradition treaty. This marked a significant turning point in Canada's ability to fill the void left in the
Chinese market amidst the trade war and presented a unique challenge to Canada-China relations (Cochrane 2018). The immediate response by China was to arrest two Canadian citizens in Beijing and to prosecute them for espionage in addition to closing its ports to Canadian canola, beef, and pork. Clearly, then, Canada has been negatively impacted in the wake of the trade war because of its close relationship with the US which sparked

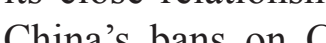
China's bans on Canadian agricultural products. Thus, Canadian agriculture was caught in the crossfire of this dispute, due to the fact that prices are especially sensitive and can be impacted heavily by diplomatic conflict (Shalal and Timmons 2019). Canadian farmers were at a further disadvantage in comparison to their American counterparts because Ottawa did not disperse the same support that the US government did, in the form of robust subsidy packages. As a result, agriculture has taken a significant hit in Canada despite the opportunities that could have been, shown by the fact that farming equipment sales were down 20.7 per cent from 2018 to 2019 (Dyck 2019). In the following sections, Canada's agricultural sector will be analyzed at a commodity-level by first examining the presence and size of the opportunity opened by the vacuum of American products. Opportunities may become more enunciated due to unpredictable and uncontrolled events, such as poor weather in previously important exporters to China. The analysis will then turn to determining whether Canadian agriculture was able to successfully penetrate the lucrative Chinese market. These claims will be substantiated by examining export data, media sources, diplomatic text, and reports by agricultural commissions.

\section{Commodity Analysis}

Cross-Nation Crustaceans: Lobster's Success in the Chinese Market

Over the past decade, China's demand for lobster has grown at breakneck speeds, with its imports increasing by 500 per cent from 2009 to 2014 (United Nations 2017, 3). This demand has been largely supplied by American products, with the Maine fishing industry exporting 363 thousand kilograms in 2010 and more than twenty times that amount in 2018 (Whittle 2019). However, following the trade hostilities that resulted in China placing heavy tariffs on US lobsters in July 2018, America exported only one million kilograms of lobster in the first half of 2019, less than a fifth of the amount exported in the previous year. This gave rise to an opportunity for Canadian lobster to fill the demand for Atlantic lobster and to break the "cartel" of (Mercer 2019). While American exports fell short on sales projections by about US $\$ 140$ million, Canadian lobster fishers increased their exporting capacity to China by more than US\$223 million (Whittle 2019). As a direct result of the trade war, Canada now controls 85 per

Chinese lobster market

Thus, Canadian lobster fishers have successfully benefited from this dispute, as Canadian lobster has overtaken the Chinese market with much lower prices than American lobster. Those in the Canadian lobster industry are now focusing on "China, China, China", narrowing in on newfound opportunities thanks to the dearth of American products in China (Mercer 2019). This focus has proved fruitful, especially in light of the fact that the value of Canadian lobster exports rose by nearly US\$9 million when comparing July 2018 to July 2017 (Withers 2019). Significantly, Maine fishers were not beneficiaries of the agriculture package from Washington, which hurt their ability to continue being competitive in China. This commodity analysis demonstrates that the successful penetration of Canadian commodities into the void left by American goods in the Chinese market is most successful when the American domestic response has not included aid for that commodity. Further, the Chinese bans on Canadian goods stemming from the arrest of Wanzhou did not include a ban on lobster, which allowed for lobster to succeed in the Chinese market.

Wheat the People: Canadian Wheat's Performance on the Chinese Market

After China placed tariffs on American wheat in 2018, its options for high-protein grain were significantly diminished (Robinson 2019). This phenomenon was furthered when Australia, 
another key wheat exporter, experienced droughts that caused significant peril to the country's grain industry, further opening a void in the market. Canada successfully seized this large opportunity, exhibited by the fact that Canada's wheat exports to China jumped nearly 200 per cent from January to November 2018 (Canadian Press 2019). This trend continued, as wheat was not impacted by following Wanzhol This allowed Canadian wheat to continually find a home in the Chinese market, shown by the fact that Canada shipped 1.9 million metric tonnes of wheat to China in the first half of 2019, up 92 per cent from 2018 (Robinson 2019). This continued through 2020, with Canadian wheat outselling its American counterpart in terms of the Chinese market for two quarters of 2020 (McMillan 2020). This followed a Chinese curtailment on buying Australian wheat due to Australia's criticism of China's handling of the COVID-19 pandemic. Thus, as neither tariffs nor political decisions inhibited the trade of wheat between Canada and China, Canadian wheat was successful in penetrating the Chinese market where there was an opportunity.

\section{Pig Heads and Pig Headedness: How Por}

\section{Fared Amidst the Trade War}

Following significant Chinese tariffs on American pork, American pig farmers saw their businesses "dry up" and Chinese consumers needed a new source of pork products (Swanson and Rappeport 2020). As the third largest importer of Canadian pork, China was already a key market for Canadian pork products, but its importance swelled once US pork imports were inhibited presenting an opportunity for Canadian pork producers (Gollom 2019). The China-Canada trade relationship trucked happily along following the tariffs, as Canadian products began penetrating the tariffs, as Canadian products began penetrating the
void left by American counterparts. This is shown by the fact that Canada exported $\$ 310$ million worth of pork to China in the first four months of 2019 (Statistics Canada 2019). However, this came to a screeching halt in June 2019, when China closed its ports to Canadian pork and beef due to the Chinese authorities allegedly finding banned additives in a Canadian shipment Gardner and Panetta 2019; Tunney 2019). This ban als (the diplomatic dispute that was a result of the Wanzhou arrest, and it is widely speculated that the arrest was a cause of this ban (Sagan 2019). Canada's agriculture minister speculated that these shipments and certificates were most likely not Canadian, but being misrepresented as such, as Canadian farmers stopped using the banned additive in question eight years prior in order to penetrate foreign markets more effectively (Gollom 2019). Following China's blanket ban on Canadian pork imports, Canadian exports were hit hard, particularly those of pig heads. This was a damaging blow to Canadian pork producers because of the specific cultural and highly regionalized culinary uses of pig heads that limit the consumer demand for them (Edmiston 2019). Even so, Canada exported much more pork to China in 2019 than in 2018, selling 22.61 per cent more in 2019 as of October compared to 2018 (Statistics Canada 2019). As diplomatic tensions cooled, China continued to purchase Canadian pork, buying record numbers in the first half of 2020 (McMillan 2020).

\section{Toying with Soy: How Chinese Policy Impacted} Soybean Farming in Canada

Canadian soybeans are faring poorly amidst the trade war and diplomatic tensions with Canada and have been largely unable to break into the Chinese market. Many Canadian commodities are priced out of the Chicago Mercantile Exchange, meaning that when US soybean futures take a hit, Canadian farmers encounter that same hit. This was especially true in the case of soybean trading in 2018 and 2019, as international prices fell from US\$10.70 per bushel in 2018 to US\$7.80 in May 2019 (Dyck 2019). Absent of a trade war, this may not have been the case, as flooding in the midwest US should have driven up prices. Thus, in the initial phases of the US-China trade war, Canadian soybean farmers were benefitting significantly, with 2018 seeing an 80 per cent surge eans in the world, controlling 60 per cent of the market and purchasing roughly 85 of the 148 million tonnes traded internationally annually, whereas the second-largest buyer, the European Union (EU), purchases fifteen million tonnes (Powell 2019). Following the trade dispute with China, American farmers were holding one billion bushels of unsold soybeans, triple the normal amount. Poor farming weather, along with American producers being tariffed out of competitiveness on the Chinese market, presented a significant opportunity to Canadian soybean producers. However, several variables meant that Canada was unable to seize a significant enough share of the Chinese market. Firstly, the American government distributed US\$28 billion in aid to farmers to ease the pain of the trade wars, which drastically reduced the perbushel price of American soybeans and allowed the sale of American bushels at aggressively low prices (Nickel 2019). As prices are internationally linked, this allowed America to push into many markets that Canada previously had solid bearings in, such as the EU. Secondly, following the arrest of Wanzhou, the plunge in Canadian soybean exports to China was sharp and swift, with exports becoming negligible. Canadian soybeans continue to struggle to sell for their value into 2020, but slight upticks in pricing and purchasing shows promise for Canadian farmers. Thus, American domestic responses to agricultural difficulty coupled with the diplomatic tensions created by Wanzhou's arrest have negatively impacted soybean penetration into the Chinese market despite an existing opportunity.

\section{Gold Oil or Fool's Gold: Canadian Canola in} China

Canola does not fit perfectly into the examination of Canadian penetration into the Chinese markets where gaps have been created by tariffs because canola is not as important to the American export market as it is to Canada's. For Canada, there was not much room to grow in terms of the Chinese market, as China was already Canada's second largest export destination for canola and American canola was not significantly impacted by the trade war (Nickel 2019). With that being said, Canadian canola seed exports to China fell by 22 per cent from 2018 to 2019 as a result of Chinese bans, with farmers planting 9 per cent less in this time period (Nickel 2019). Ottawa responded by increasing coverage available for canola exporters, seeking to reduce trade risks. However, the Canadian response was not enough to keep Canadian canola farmers exporting at normal rates. Canada attempted to turn to Europe to fill the gaps, hoping the biodiesel industry in Europe would pick up the slack (Edmiston 2019; Robinson and Durisin 2019). This might have allowed Canada to bounce back after two Chinese decisions in March 2019 revoked importing licenses for Canadian canola due to "pests" in shipments, an accusation speculated to have been a response to Wangzhou's arrest (Robinson and Durisin 2019). However, Canada only supplied limited amounts of European demand in the past and struggled to gain access to the market, as Canadian farmers are not certified by the EU (Shalal and Timmons 2019; Robinson and Durisin 2019). Other markets that can absorb some canola importation include Pakistan and Bangladesh, although Canada has been experiencing troubles penetrating those markets to the same degree it used to sell to China.

In the absence of gaining meaningful access to new markets, Canada's canola exports continued to depend on the hope of the Chinese market. Although canola remains constrained, exports of its seed to China in March 2020 were three times that of February's and the largest since December 2018 (McMillan 2020). Thus, in the case of canola, this commodity was unsuccessful in exporting to the Chinese market amidst the trade war due to the diplomatic decisions that may relate to the arrest of Wanzhou on American orders. However, in 2020, demand for Canadian canola soared, and China began obtaining the product through third party countries such as the United Arab Emirates (Nickel and Gu 2020). Therefore, although this export product was not trying to fill a gap, it is an important element to examine in understanding how Canadian agriculture is impacted by American trade and diplomatic decisions. Canola demonstrates a clear example of a commodity that was initially harmed by Canada's relationship with the US, but eventually managed to find its way back to Chinese consumers. 


\section{Analysis: If Everybody Loses, Does \\ Canada?}

The commodity-level analysis conducted in this paper demonstrates that the opportunities presented to Canadian agriculture were asymmetrically distributed across different product sectors. Moreover, the ability for producers to seize these opportunities were impacted by Canada's relationship with the US, tariffs levied by China, and global weather patterns. The arrest of Meng Wanzhou was a significant detriment to Canadian economic opportunities in China, as the arrests were likely related to Chinese bans on commodities such as canola and pork. Trade wars in the future between major economies may be beneficial for Canada in the absence of idiosyncratic diplomatic spats akin to the situation with Wanzhou.

Even if Canadian products were able to successfully penetrate the Chinese market in consideration of all five of the aforementioned commodities, that is not necessarily cause for celebration for Canadian agriculture. Farming is based on predictions and educated guesses during planting seasons, in which seeding, ordering, and cultivating is done months in advance with little insight into the unexpected turns that may take place in the international political economy or among global trading relations. This has produced a fair deal of uncertainty in the market and shortterm contracts have resulted in "nervousness" on both sides (Dyck 2019). This inhibits the ability of farmers to comfortably invest in their operations and may have drastic impacts on commodity pricing in the future. In theory, the decreased availability of American products for Chinese consumption could have created a larger place for Canadian trade to infiltrate; however, following a series of diplomatic and economic events, Canadian agriculture was only able to take advantage of the Chinese market under very specific conditions. This gave rise to a situation in which Canadian farmers ended up owing a record-high US $\$ 106$ billion by 2019 (Edmiston 2019). In early 2020, the US and China negotiated a trade agreement that was supposed to result in China buying significant amounts of American agricultural goods (Hiltzik 2020).

\section{Conclusion}

The US-China trade war has had significant and asymmetric impacts on the global trading environment. As has been established, political decisions, commodity pricing, and tariff rates variables to examine in trying to ascertain how a commodity in the trying to ascertain how a commodity in the Canadian agricultural sector was impacted by the trade war. Through an analysis of Canadian trade, I have shown how these variables account for much of the commodity-level discrepancies in examination of the upshots of the trade war. Despite the potential US-China potential opportunities created by the US-China trade war, some Canadian products ability to seize these opportunities was damaged significantly by the US issuing an extradition request for Chinese executive Meng Wanzhou, which turned China-Canada relations sour and damaged their trading relationship. As the trade war continued to unfurl, the COVID-19 pandemic and Joe Biden's presidential win derailed possible trade talks between China and the US.

This paper's exploration of the trade war's impact on the Canadian agricultural sector raises several questions regarding Chinese market accessibility, Canadian diplomatic relations, and the US' influence on Canadian trading relationships. These include: What additional variables may emerge that could impact commodity penetration into the Chinese import market? What ways might the Canadian government use domestic policy tools to help farmers stay competitive looking ahead to Biden's impending presidency? Can the commodity-level analysis approach be applied effectively to other sectors than the agricultural one? These questions may serve as a guide for understanding new possibilities for threats to and opportunities for Canadian trade and diplomacy.

\section{References}

Al-Rodhan, Khalid R. 2007. "A Critique of the China Threat Theory: A Systematic Analysis." Asian Perspective 31, no. 3: 41-66. www.jstor org/stable/42704598.

Aljazeera. 2019. "Huiyao Wang: US-China trade war 'unprecedented' and 'alarming'. Aljazeera, December 28, 2019. 2019.https://www.aljazeera.com/programmes/talktojazeera/2019/12/ huiyao-wang-china-trade-war-unprecedented-alarming-191226083040164.html.

Kalsie, Anjala \& Ashima Arora. 2019. "US-China Trade War: The Tale of Clash Between Biggest Developed and Developing Economies of the World." Management and Economics Research Journal, vol. 5, 1-12.

World Integrated Trade Solution. 2018. "Canada Trade Summary.” Retrieved October 2020. https://wits.worldbank.org/CountryProfile/en/ Country/CAN/Year/LTST/Summarytext.

Committee on Ways and Means US House of Representatives. 2011. "The U.S.-China Economic Relationship: Hearing, First Session,” One Hundred Twelfth Congress, United States Government Information, McGill Library. Retrieved October 25, 2020. https://www.govinfo. gov/content/pkg/CHRG-112hhrg72874/pdf/ CHRG-112hhrg72874.pdf.

The Canadian Press. 2019. "Canadian wheat exports to China soar amid U.S.-China tariff dispute.” The Financial Post, January 18, 2019. https://business.financialpost.com/pmn/commodities-business-pmn/agriculture-commodities-business-pmn/canadian-wheat-exports-tochina-soar-amid-u-s-china-tariff-dispute.

Cochrane, David. 2018. "Canada had no choice but to arrest Huawei executive at Washington's request: expert." Canadian Broadcasting Corporation, December 07, 2018. https://www. cbc.ca/news/politics/meng-huawei-extradition-1.4937146https://www.cbc.ca/news/politics/meng-huawei-extradition-1.4937146.

Dyck, Toban. 2019. "U.S.-China trade wars 'a whole new kettle of fish' for Canadian farmers feeling the fallout." Financial Post, August 12, 2019. https://business.financialpost.com/commodities/agriculture/u-s-china-trade-wars-awhole-new-kettle-of-fish-for-canadian-farmersfeeling-the-fallout.

Edmiston, Jake. 2019. "No other sector in our economy is getting slammed as hard as farmers in the global trade war." Financial Post, August 15, 2020. https://business.financialpost.com/ commodities/agriculture/trade-wars-bringdeep-uncertainty-disrupted-supply-chains-battered-bottom-lines-to-farming-industry.

The Embassy of the United States in Canada,

"U.S-Canada Economic Relations."n.d. https:// photos.state.gov/libraries/canada/303578/pdfs us-canada-economic-relations-factsheet.pdf.

Gardner, Lauren and Alexander Panetta. 2019. "Canada decides: Trudeau faces heat over handling of China and trade war." Politico, September 16, 2019. https://www. politico.com/story/2019/09/16/canada-china-trade-war-1704947.

Gollom, Mark. 2019. "Why China has a beef with Canadian meat exports." Canadian Broadcasting Corporation, June 27, 2019. https:// www.cbc.ca/news/business/china-pork-beefban-1.5190574.

Globefish Research Programme. 2017. "The world lobster market." Food and Agricultural Organization of the United Nations. http:// www.fao.org/3/a-i6816e.pdf.

Harrell, Peter. 2019. "The U.S.-Chinese Trade War Just Entered Phase 2.” Foreign Policy, December 27, 2019. https://foreignpolicy. com/2019/12/27/united-states-china-trade-warfought-export-import-controls-investment-restrictions-sanctions.

Hass, Ryan and Denmark, Abraham. 2020. "More pain than gain: How the US-China trade war hurt America." Brookings, August 25, 2020. https://www.brookings.edu/blog/ order-from-chaos/2020/08/07/more-pain-thangain-how-the-us-china-trade-war-hurt-america/

Heeb, Gina. 2019. "Trade wars could slow glob al growth to weakest pace since financial crisis, IMF warns". October 15. Business Insider. https://markets.businessinsider.com news/stocks/trump-trade-war-impact-oneconomy-imf-sees-slowing-growth-2019-101028600779\#: : :text=Trade\%20tensions $\% 20$ could $\% 20$ slow $\% 20$ global,the $\% 20$ lowest $\% 20$ level $\% 20$ since $\% 202009$

Hiltzik, Michael. 2020. "Column: How China took Trump to the cleaners in their big trade deal." Los Angeles Times, October 27, 2020. Retrieved from https://www.latimes.com/ 
business/story/2020-10-27/hiltzik-china-beattrump-in-trade-deal.

Library of Congress. 2010. "U.S. Trade with Chi na: Selected Resources." https://guides.loc.gov/ us-trade-with-china.

McMillan, D. 2020. Canada-China ag trade better but remains precarious." Producer, June 4, 2020. https://www.producer.com/2020/06/canada-china-ag-trade-better-but-remains-precarious/.

Mercer, Greg. 2019. "The U.S.-China trade war is a boon for Atlantic Canada's lobster harvesters. But what's the catch?" The Globe and Mail, November 29, 2019. https://www. theglobeandmail.com/canada/article-the-uschina-trade-war-is-a-boon-for-atlantic-canadaslobster/.

Nickel, Rod. 2019. "With China dispute leading to reduced plantings, Canada expects canola harvest to be 9 per cent smaller." Financial Post, August 28, 2019. https://business.financialpost. com/commodities/agriculture/with-china-dispute-leading-to-reduced-plantings-canada-expects-canola-harvest-to-be-9-per-cent-smaller

Nickel, Rob and Hallie Gu. 2020. "Demand for Canadian canola soars as shippers find roundabout way to reach China." Global News, August 10, 2020. https://globalnews.ca/ news/7262233/canadian-canola-prices-shipping-china/.

Powell, Naomi. 2019. "Canadian farmers are about to harvest 6 million tonnes of soybeans - the worry is who will buy them?" Montreal Gazette, October 28 , 2019. https://montrealgazette.com/commodities/agriculture/canadian-farmers-areabout-to-harvest-6-million-tonnes-of-soybeans-the-worry-is-who-will-buy-them/ wcm/95b8bdbf-139a-466f-a951-40cef-

932527c?utm_medium $=$ Social\&utm_source $=$ Facebook\&fbclid=IwAR0oRWZ111 eO0IZVkTLuww-IZKO6PloUUw0NRpqwEI0ah8bsYDbjVGwRhJA\#Echobox=1572281977.

Rioux, Hubert and Stéphane Paquin. 2019.

"Perspectives on the Resurgence of Economic Nationalism in North America: A Long-standing and Far-reaching Phenomenon". European
Review of International Studies, 6(3), 3-6. doi:10.2307/26914890.

Robinson, Ashley. 2019. "As canola spat steals headlines, China quietly buys other Canadian crops." Financial Post, August 15, 2019. https://business.financialpost.com/commodities/agriculture/as-canola-spat-steals-headlineschina-quietly-buys-canada-crops.

Robinson, Ashley and Durisin, Megan. 2019.

"As China spat hits hard, Canada's canola exporters see alternatives in EU biofuel industry", Bloomberg News. August 26. https://business. financialpost.com/commodities/agriculture/ as-china-spat-hits-hard-canadas-canola-exporters-see-alternatives-in-eu-biofuel-industry.

Rushe, Dominic. 2019. "Here are the reasons for Trump's economic war with China." The Guardian, August 23, 2019. https://www. theguardian.com/us-news/2019/aug/23/trumpchina-economic-war-why-reasons.

Sagan, Aleksandra. 2019. "China's ban on Ca nadian meat will lead to 'huge' losses, industry says." Global News, June 26, 2019. https:// globalnews.ca/news/5435149/china-canada-meat-ban-industry/.

Shalal, Andrea and Timmons, Heather. 2019. "Ev erybody loses': Trump's trade wars have created suffering economies around the world." Financial Post, October 21, 2019. https://business.financialpost.com/news/economy/falloutfrom-trumps-trade-wars-felt-by-economiesaround-the-world-2.

Statistics Canada. 2019. "Agriculture and AgriFood: Red Meat Exports by Country - year to date cumulative." Government of Canada, December 06, 2019.http://www.agr. gc.ca/eng/industry-markets-and-trade/ canadian-agri-food-sector-intelligence red-meat-and-livestock/red-meat-and-livestock-market-information/exports/red-meat-exports-by-country/?id=1419965032803.

Swanson, Ana, and Paul Mozur. 2019. "U.S.

Blacklists 28 Chinese Entities Over Abuses in Xinjiang.” New York Times, October 7, 2019. https://www.nytimes.com/2019/10/07/us/politics/us-to-blacklist-28-chinese-entities-overabuses-in-xinjiang.html.
Swanson, Ana and Alan Rappeport. 2020.

"Trump's Trade Appeals to China Still Left

Farmers Reeling." New York Times, June 19 , 2020. https://www.nytimes.com/2020/06/19/ business/economy/trump-china-trade-warfarmers.html.

"Timeline: Key dates in the U.S.-China trade war." Reuters, October 10, 2019. https://www. reuters.com/article/us-usa-trade-china-timeline/ timeline-key-dates-in-the-us-china-trade-waridUSKBN1WP23B.

Tunney, Catharine. 2019. "Canadian pork and beef exports to China resuming, says Trudeau." Canadian Broadcasting Corporation, November 09, 2019. https://www.cbc.ca/news/politics/ canada-pork-beef-trudeau-1 5348532

"Trade war leaves both US and China worse off." The United Nations Conference on Trade and Development (UNCTAD), November 6, 2019. https://unctad.org/news/trade-war-leaves-bothus-and-china-worse.

"Presidential Executive Order on Establishing En hanced Collection and Enforcement of Antidumping and Countervailing Duties and Violations of Trade and Customs Laws." The White House, March 31, 2017.

https://www.whitehouse.gov/presidential-actions/presidential-executive-order-establish-

ing-enhanced-collection-enforcement-antidumping-countervailing-duties-violations-trade-customs-laws/.

Whittle, Patrick. 2019. "Canadian lobster exports boom amid U.S. trade tensions with China." Canadian Broadcasting Corporation, August 25, 2019. https://www.cbc.ca/news/canada/nova-scotia/u-s-exports-to-lobster-loving-chinago-off-cliff-amid-tariffs-1.5259453.

Withers, Paul. 2019. "U.S.-China trade war boosts sales of Canadian live lobster exports to China." Canadian Broadcasting Corporation, September 28, 2019.

https://www.cbc.ca/news/canada/nova-scotia/us-trade-war-drives-soaring-canadian-live-lobster-exports-to-china-1.4838547.

Woo, Wing Thye. 2018. "A US Perspective on China's External Economic Disputes in the past 40 Years and in the Coming 40 Years."
China's 40 Years of Reform and Development: 1978-2018, edited by Garnaut Ross, Song Ligang, and Fang Cai, 637-58. Acton ACT, Australia: ANU Press. www.jstor.org/stable/j. ctv5cgbnk.39.

Zhang, Yuhan. 2018. "The US-China Trade War: A Political and Economic Analysis." Indian Journal of Asian Affairs 31, no. 1/2: 53-74. www.jstor.org/stable/26608823. 